кандидат социологических наук, доцент кафедры управления персоналом Белгородского государственного национального исследовательского университета

\section{СОЦИАЛЬНЫЕ РИСКИ ИМИТАЦИИ ОБРАЗОВАТЕЛЬНЫХ ПРАКТИК В РОССИИ [1]}

Аннотация:

В статье рассмотрены причины применения понятия «имитация» в отношении образовательных практик в России. Определен понятийный и категориальный аппарат заяєленной проблемы. Обозначена необходимость изучения проблемы образовательных симулякров в контексте всего российского образовательного пространства, не ограничиваясь рамками высшего образования Раскрыты понятия "социальные риски», "образовательные имитации» и влияние их на деятельность высших учебных заведений. Утверждается, что риск образовательных симулякров представляет собой угрозу нежелательных отклонений от ожидаемого состояния системы образования России в будущем. Процесс эффективной модернизации системы образования подменяется имитационными образовательными практиками или симулякрами. Социальные последствия производства симулякров знаний принимают угрожающий характер и заключаются в отсутствии базовых навыков обучаемости и деградации учащейся молодежи и российского общества в целом.

Ключевые слова:

риск, имитация, образование, образовательные практики, феномен, социум, трансформация, угрозы, социальные риски, симулякры, мнимые знания.

\author{
PhD in Social Science, \\ Associate Professor, \\ Human Resources Management Department \\ Belgorod State National Research University
}

\section{SOCIAL RISKS OF EDUCATIONAL PRACTICES SIMULATION IN RUSSIA [1]}

Keywords:

risk, simulation, education, educational practices, phenomenon, society, transformation, threats, social risks, simulacra, pseudo-knowledge.

Радикальные социально-экономические, политические и социокультурные изменения, которые происходят в России в последнее время, затрагивают практически все сферы общественной жизни, все социальные институты. Не стала исключением и система образования. Модернизация и реформирование российского образования нуждаются во всестороннем исследовании, так как риски становятся характерными особенностями современных радикальных изменений.

По общепринятому представлению риск расценивается как возможная опасность, угроза вероятного неблагоприятного или нежелательного результата действий или развития событий. Можно сказать, что риск - это угроза нежелательных отклонений от ожидаемого результата в будущем.

При тех структурных и функциональных изменениях, которые происходят в современном российском обществе, возрастает и количество социальных рисков. К социальному напряжению приводят неустойчивость и неопределенность общества, а также ускорение социетальных изменений.

Социальные риски - это риски социального происхождения, вероятные опасности, угрозы нарушения нормального для общества социального положения [2].

Рассмотрим социологические подходы к пониманию социального риска, социальных имитаций, а также образовательных практик и их симулякров.

В социологии социальному риску уделяется достаточно много внимания. Первыми социальный риск стали изучать такие зарубежные ученые, как Н. Луман, У. Бек, А. Вилдавски, Э. Гидденс, П. Словик, К. Дейк, С. Лихейстайн и др. В России теоретическое изучение социальных рисков началось с работ С.А. Кравченко, В.И. Зубкова, Н.А. Мешавкиной, О.Н. Яницкого, Ю.А. Зубок и других исследователей.

Проблема социальных рисков существовала на протяжении всей истории российского государства, однако российские ученые начали ее активное исследование только в 1990-х гг. 
Особенно острой и актуальной эта проблема стала в последние десятилетия, когда возникновению и нарастанию социальных рисков способствует общая тенденция развития мировой цивилизации в условиях глобализации и открытости социальных систем. В связи с этим современное общество представляет собой сложно организованную систему с социальными процессами, которые постоянно изменяются.

Существенным риском для российского общества стали имитации. В.П. Бабинцев определяет имитации как «систему действий, в ходе которых реальные значения и смыслы замещаются и подменяются фрормальным воспроизведением операций и процедур, сопровождаемым их демонстрацией, декларацией и декорацией» [3, с. 92].

Социальные имитации в современном обществе стали вполне привычным явлением. Это подтверждает исследование специалистами процессуальных характеристик общественной жизни, где в подавляющем большинстве социальные процессы характеризуются как имитационные [4].

О феномене социальных имитаций пишут В.П. Бабинцев, Ю.Г. Волков, З.Т. Голенкова, Е.В. Красавина, Ж.Т. Тощенко, Т.А. Шалюгина и др.

Одним из примеров социальных имитаций являются образовательные имитационные практики. В социологии понятие «образовательные практики» встречается в трудах О.В. Власовой, Ю.В. Латова, А.Н. Пинчук, Н.А. Селиверстовой, Е.А. Смирновой и др.

Образовательные практики можно рассматривать как некие привычки учиться определенным образом, сформированные в ситуации решения познавательно-исследовательских задач. В процессе интенсификации познавательного интереса и активности индивида они постоянно актуализируются.

А.Н. Пинчук предлагает трактовать образовательные практики как совокупность привычных действий, навыков, сконструированных в условиях приобретения и усвоения определенных знаний [5].

Современные образовательные практики становятся предметом исследования многих социологов. Феномен образовательных практик в контексте модернизации российской системы образования рассматривается сквозь призму социологии повседневности и социологии образования.

По нашему мнению, одним из важнейших фракторов риска социальных имитаций являются имитации в образовании. Здесь субъектом социальных рисков является учащаяся молодежь, чья основная деятельность заключается в получении образования. Сегодня в условиях социальных трансформаций и неопределенности она наиболее подвержена различного рода рискам, в том числе социальным.

Имитация образовательных практик («мы как бы учим, а они как бы учатся») представляет собой актуальную социетальную проблему российского общества, которая вызвана комплексом социокультурных, социально-экономических и социально-политических противоречий [6].

Имитации в образовании представляют собой симулякры. Термин «симулякр» был введен фрранцузским философом Ж. Бодрийяром как символ несуществующих объектов [7, p. 11].

Проблема симулякров в российском образовании крайне мало исследована. По мнению доктора социологических наук Ю.В. Латова, «это объясняется тем, что здесь наблюдается своего рода “преступление без жертв": и те, кто желает получить диплом, не подкрепленный знаниями, и те, кто помогает желающим получить такие дипломы, видят в имитации институтов образования возможность удовлетворить свои потребности» [8, с. 212].

Однако, по нашему мнению, проблема образовательных симулякров не ограничивается только высшим образованием. Ее следует рассматривать в контексте всего российского образовательного пространства.

Рассмотрим основные проблемные зоны имитационных образовательных практик.

В высшие и средние специальные учебные заведения молодежь приходит после школы. Вполне рационально начать рассмотрение образовательных имитаций именно с этой образовательной ступени.

Общество постепенно приходит к пониманию, что ЕГЭ в школах не является в полной мере эфффективным инструментом контроля знаний и обладает очевидными недостатками. Школьники вместо развития креативных и интеллектуальных способностей вынуждены ориентироваться на решение тестов. Важнейшие для развития творческих начал годы практически не используются для этой цели. Дети не получают знания в школе, а по сути с первого класса готовятся к тестам единого государственного экзамена. Происходит подмена самого понятия получения знаний.

Во многих школах практикуется дополнительное репетиторство (за определенную плату) с целью подготовки к ЕГЭ. Это означает, что учитель не стремится к тому, чтобы дать необходимые знания своим ученикам, а, наоборот, заинтересован в дополнительном обучении с почасовой оплатой его работы. По нашему мнению, это и есть один из ярких примеров имитационных образовательных практик. 
Проблема также заключается в том, что огромное число представителей молодежи не хочет или даже не может учиться всерьез. С ранних лет им навязывается потребительская идеология: зачем изнурять себя учебой, если можно получить высшее образование за деньги? В результате неподготовленные школьники приходят учиться в пединституты, а после их окончания возвращаются учить детей в школах. Исправлять школьные недоработки с каждым годом становится все труднее. Поэтому, по нашему мнению, эффективная модернизация системы образования должна начинаться в пединституте, где готовят учителей. Для этого еще в школе нужно готовить будущих ученых и вузовских преподавателей. Это подтверждает опыт стран, прошедших модернизацию образования. Однако процесс эфрфективной модернизации системы образования на практике подменяется имитационными образовательными практиками или симулякрами.

Социальные последствия производства симулякров знаний принимают угрожающий характер. Современные реалии таковы, что при получении среднего образования не обязательно приобретать знания, достаточно усилить подготовку к ЕГЭ и постараться успешно сдать его и набрать максимальные баллы. Высокие баллы ЕГЭ дают возможность поступить на бюджетное отделение одного из выбранных вузов. Но для того, чтобы получить высшее образование, не обязательно получать только высокие оценки. Для тех выпускников средних школ, которые получили посредственные оценки, также открыты двери практически всех вузов для обучения на коммерческой основе. Туда можно поступить и с тройками, потому что мест в вузах больше, чем выпускников. Особенно это актуально сейчас, когда для России характерна так называемая «демографическая яма».

Кроме того, начиная с первого курса у молодых людей вырабатываются определенные образовательные практики, связанные с необходимостью усвоения учебного материала. Следует отметить, что не всегда эти практики являются легитимными.

Например, студенты могут выполнять курсовые работы самостоятельно и для этого собирают необходимый материал, изучают литературные источники и монографии, а можно наблюдать и другие фрормы поведения, когда студенты предпочитают за определенную плату заказать выполнение этих работ. То же самое происходит с написанием выпускных квалификационных работ. Студенту важно получить диплом о высшем образовании, знания не являются приоритетом. Так происходит получение мнимых знаний.

В современных образовательных технологиях проблема производства мнимых знаний стоит достаточно остро. По нашему мнению, именно мнимые знания являются основой имитационных образовательных практик.

В толковом словаре русского языка С.И. Ожегова и Н.Ю. Шведовой понятие «мнимый» трактуется как «воображаемый, кажущийся, притворный». Исходя из этого, можем предложить авторскую трактовку понятия «мнимые знания»: фоорма существования и систематизации результатов познавательной деятельности человека, полученная с помощью использования имитационных образовательных практик. Мнимые знания можно расценивать как «ненастоящие знания», а точнее симулякры знаний.

В больших количествах симулякры знаний можно наблюдать и в нынешних системах заочного и дистанционного образования, где студенты не стремятся получить необходимые знания и не уделяют достаточно времени учебному процессу.

Недостаток абитуриентов и наличие коммерческого образования ставит вузы в условия, когда они заинтересованы в каждом студенте. Отчислить неуспевающего студента очень трудно, поэтому дипломы о высшем образовании за редким исключением получают все обучающиеся в вузе.

Мы разделяем точку зрения Ю.В. Латова, который утверждает, что «подмена производства знаний производством симулякров знаний ведет к падению экономической эффективности» [9, c. 215]. Это проявляется не только в замедлении роста производительности труда, но и в коррупции.

Имитационные образовательные практики несут в себе значительные социальные риски и девальвируют ценность диплома о высшем образовании. Положение на рынке труда складывается таким образом, что при переизбытке выпускников вузов в России наблюдается кадровый кризис. Хорошо образованных, компетентных людей, способных решать серьезные задачи, катастрофически не хватает практически во всех сферах экономики страны.

Получение «суррогатного диплома» и мнимых знаний несет в себе риски того, что выпускник не сможет подтвердить свои знания на практике, добиться высокой производительности труда и выполнить поставленные перед ним задачи. Также имитация образовательных практик влечет за собой такие социальные риски, как снижение качества подготовки вузами специалистов для народного хозяйства из-за общедоступности высшего образования и несоответствие подготовки выпускников вузов потребностям экономики и рынка труда. 
Высшее образование всегда рассматривалось как система дополнительной аккультурации и социализации молодежи, как главный антропологический и интеллектуальный ресурс. Подмена качественного образования симулякрами несет в себе такие социальные риски, как отсутствие базовых навыков обучаемости и деградация учащейся молодежи, а следовательно, и общества в целом.

\section{Ссылки и примечания:}

1. Статья выполнена при поддержке гранта Президента Российской Федерации МK-1236.2018.6 «Имитация образовательных практик маргинальными группами населения: угроза региональной безопасности».

2. Акулич М.М., Комбарова Е.В. Социологическое изучение социальных рисков: история и современность // Вестник Тюменского государственного университета. 2008. № 4. С. 55-62.

3. Бабинцев В.П., Ушамирская Г.Ф. Субкультура бюрократии в региональном хронотопе // Регионология. 2014. № 1 (96). C. 87-98.

4. Закирова Т.В. Феномен симулякра как проявление социальной имитации // Вестник Оренбургского государственного университета. 2014. № 7 (168). С. 50-53.

5. Пинчук А.Н. Образовательные практики современных студентов социально-гуманитарного профиля подготовки : автореф. дис. ... канд. социол. наук. Майкоп, 2017. 20 с.

6. Селиверстова Н.А. К интерпретации понятия «образовательные практики» // Высшее образование для XXI века : докл. и материалы XIII Междунар. науч. конф. (Москва, 8-10 дек. 2016 г.) : в 2 ч. Секция 2. Социология образования / отв. ред. Н.А. Селиверстова. Ч. 1. М., 2016. С. 89.

7. Baudrillard J. Simulacres et simulation. P., 1981. 230 p.

8. Латов Ю.В. Симулякры знаний и образовательные неравенства в сфере андрагогического образования // Мониторинг общественного мнения: экономические и социальные перемены. 2014. Вып. 2 (120). С. 211-219.

9. Там же. С. 215

\section{References:}

Akulich, MM \& Kombarova, EV 2008, 'Sociological study of social risks: history and contemporaneity', Vestnik Tyumenskogo gosudarstvennogo universiteta, No. 4, pp. 55-62, (in Russian).

Babintsev, VP \& Ushamirskaya, GF 2014, 'The subculture of bureaucracy in the regional chronotope', Regionologiya, No. 1

(96), pp. 87-98, (in Russian).

Baudrillard, J 1981, Simulacres et simulation, Paris, 230 p., (in French).

Latov, YuV 2014, 'Knowledge simulacra and education inequalities in andragogic education', Monitoring of Public Opinion: Economic and Social Changes, Iss. 2 (120), pp. 211-219. https://doi.org/10.14515/monitoring.2014.2.015.

Pinchuk, AN 2017, Educational practices of modern students majoring in Social Science and Humanities, PhD thesis abstract, Maykop, 20 p., (in Russian).

Seliverstova, NA (ed.) 2016, 'The interpretation of the concept of educational practices', Vyssheye obrazovaniye dlya XXI veka: dokl. i materialy XIII Mezhdunar. nauch. konf. (Moskva, 8-10 dek. 2016 g.), in 2 parts, Part 1, Moscow, p. 89, (in Russian). Zakirova, TV 2014, 'The phenomenon of simulacra as a manifestation of social imitation', Vestnik Orenburgskogo gosudarstvennogo universiteta, No. 7 (168), pp. 50-53, (in Russian). 